\title{
THE SIGNIFICANCE OF CORPORATE COLLECTIVE POWER TO NEW LABOUR'S PROJECT: MARKET VALUES, CORPORATE REGULATION AND THE POSSIBILITIES FOR A PROGRESSIVE POLITICS
}

\author{
Gary Wilson, School of Law, University of Keele*
}

"The pure and sinless did not exist, or else died unnoticed and with no obituary. The idea seemed persuasive. Those who merited obituaries usually achieved things, fought for their ideals, and when locked in battle, it wasn't easy to remain entirely honest and upright. Today's battles were all for material gain, anyway. The crazy idealist was extinct- survived by the crazy pragmatist ..."

A. Kurkov, Death and the Penguin (2003) 61

\section{Introduction}

This paper seeks to sketch the historical development of the political economy of the corporation in the United Kingdom from the onset of modernity to the beginning of the twenty-first century, in order to contextualise the significance of corporate power to the politics of New Labour and to the broad possibilities offered by the major review of company law legislation commenced in $1998 .{ }^{1}$ It will be argued that the way in which the corporate entity is theorised and regulated is not simply a subject for abstruse academic debate or for resolution at a technical level by expert committee (though, for sure, both do have an important role) but is rather a matter of central import to the broader trajectory of modern industrial societies, both in terms of the appropriate regulation of collective power and the generation of wider values beyond those of market individualism. Accordingly, it thus posits a key issue for mainstream progressive politics.

In order to substantiate this claim it will be necessary to interleave an analysis of the pertinent constructs underpinning New Labour's political programme (notably globalisation, post-Fordism, and the recent work of Anthony Giddens ${ }^{2}$ on the Third Way and progressive politics); the different

* The author would like to thank Michael Cardwell, Matthew Weait and Sarah Wilson for their encouragement and comments. This article is written as at 1 August 2005: the Company Law Reform Bill has subsequently been put before Parliament.

1 Following the publication of Modern Company Law for a Modern Economy: Final Report (2001) by the Company Law Review Steering Group in June 2001, the Government has issued two White Papers setting out proposals for consultation on a new Companies Act: see Modernising Company Law (July 2002; Cm 5553) and Company Law Reform (March 2005; Cm 6456).

2 The principal works are as follows: Beyond Left and Right: The Future of Radical Politics (1994); The Third Way: The Renewal of Social Democracy (1998); The 
approaches taken to the legal theorisation of the corporate entity; and the present extensive corporate law reform programme in the United Kingdom. ${ }^{3}$ Particular emphasis will be given to attempting to capture the way in which consideration of the collective power inherent in corporations would appear to be notable largely by its absence in both corporate law theory and New Labour's overall worldview. It will be suggested that the relative invisibility of this collective power has potentially profound ramifications for the possibilities inherent in a progressive politics (and thus for society as a whole) given the juxtaposition of New Labour's well known desire to be business friendly ${ }^{4}$ and the increasing emphasis placed by New Labour politicians upon the role of a distinctive set of values as the marker of a progressive agenda. ${ }^{5}$

The quote from Andrey Kurkov's Death and the Penguin at the head of this article might indeed be thought to be prescient (the novel was first published in 1996) when applied to the common critiques of New Labour's general pro-business/pro-market philosophy and period in office, especially from those on the traditional Left. At the same time it would not seem too far from the mark to characterise the Labour Party's own trajectory over the last 25 years as shifting from 'crazy idealism' to 'crazy pragmatism'. The Party's initial reaction to Thatcherism was to maintain a relatively ideologically pure socialist position that placed the party in the political wilderness for over a decade (the manifesto for the 1983 general election ${ }^{6}$ was famously dubbed 'the longest suicide note in history'). As a direct response to this Blair's internal party reforms of the mid-1990's ${ }^{7}$ led to the creation of New Labour and the development of a rather murky set of social democratic principles which, whilst leading to repeated electoral success (an unprecedented third term was achieved in May 2005), sacrificed many fundamental Labour Party

Third Way and its Critics (2000); and Where Now for New Labour? (2002). Edited collections comprise: The Global Third Way Debate (2001); The Progressive Manifesto: New Ideas for the Centre-Left (2003); with W. Hutton, Global Capitalism (2000); and with P. Diamond, The New Egalitarianism (2005).

3 Insolvency law has also been extensively reformed in line with the New Labour emphasis on fostering entrepreneurship through seeking to reduce the stigma of failure in personal insolvency and to develop an enhanced rescue culture in corporate insolvency: see Insolvency Act 2000, Enterprise Act 2002 and G. Wilson and S. Wilson, 'Responsible Risk-Takers: Notions of Directorial ResponsibilityPast, Present and Future' (2001) 1 J. Corp. Law Studies 211.

4 At each general election since 1997 the party has produced a detailed separate business manifesto. Blair's speech (28 April 2005) launching the 2005 business manifesto was headed 'Labour is the Party of Business.'

5 See, e.g. T. Blair, 'Progressive Values', (Spring 2005) 4.1 Progressive Politics 5763. This journal is sponsored by Policy Network, an international independent think tank for the development of progressive ideas of the centre-left chaired by Peter Mandelson.

${ }^{6}$ A New Hope for Britain: policies included Keynesian macro-economics, renationalization of privatized industries and withdrawal from the European Community.

7 It is important to note that Blair was able to build upon work undertaken by the two previous Labour Party leaders, Neil Kinnock and John Smith, but the New Labour soubriquet that has been used since shortly after Blair's election as leader in 1994 was clearly intended to signify a fundamental re-configuration of party policy. 
precepts $^{8}$ in order, according to the modernisers, to regain relevance in the profoundly changed circumstances of a globalized world; and according to the critics, to facilitate the pragmatic pursuit of power. ${ }^{9}$

The burden of this article will be to argue that there is substance to the New Labour programme (whether labelled as the Third Way or reincarnated under its current appellation progressive politics) but that to date the nature of corporate collective power has been both inconsistently recognised and inadequately theorised in this context. This has created a serious lacuna, which is particularly important given the prominence of the business sector in the present United Kingdom political firmament and the stress that is laid upon values by those professing a progressive politics. As was noted by a former Secretary of State for Trade and Industry, Stephen Byers MP (when promoting discussion about corporate governance as part of the independent company law review process), the nature of the prospective reform of United Kingdom corporate law is thus of crucial significance well beyond the narrow parameters of company law itself:

"The reason this debate is important is that the way that companies are allowed to operate defines the nature of the market economy that we live in. The key to shaping the market in ways that achieve our twin objectives of efficiency and social justice lie in the framework of rules within which companies do business and make a profit. So company law and corporate governance are at the heart of the debate about the kind of society we want and the nature of our economy." 10

It is interesting to note that, whilst Byers' initial sentence is addressing the market economy, there is subsequently clear recognition of the pervasive (indeed, to those of a critical disposition, corrosive) nature of the broad highly individualist values and modus operandi originating in the market domain with respect to society more generally. ${ }^{11}$ Given that New Labour's preference for market solutions has also been vigorously extolled within the sphere of the European Union, the United Kingdom is one of the key sponsors of the Lisbon Agenda, ${ }^{12}$ it is not surprising that this issue has

8 Most notably, at least in symbolic terms, by the repeal of Clause 4 of the Party's constitution (re common ownership of the means of production via nationalization) at the October 1994 party conference.

9 See T. Blair, The Third Way: New Politics for a New Century (1998). Blair's frank admission of the pragmatic nature of the project, 'what matters is what works to give effect to our values' (ibid., p.4) (together in later years with an undue reliance on presentation or 'spin') has provided much grist to the critics' mill: see, e.g. the articles in the special issue of Marxism Today (December 1998).

10 Speech made at the TUC / IPPR seminar on corporate governance (7 June 2000).

11 Byers' subsequent resignation as a Minister over the Railtrack administration in May 2002 and recent admission (in an ultimately unsuccessful High Court action brought against him for public misfeasance by aggrieved Railtrack shareholders) that he told an untruth to Parliament, are in this light especially unfortunate from a governance perspective. For a discussion of some of the issues involved, together with an analysis the nature of Railtrack's successor company Network Rail, see L. Whitehouse, 'Railtrack is Dead - Long Live Network Rail? Nationalization under the Third Way' (2003) 30 J. of Law \& Soc 217.

12 The Agenda was adopted at the Lisbon European Council in 2000 with the principal aim of making the European Union the most dynamic and competitive 
resonated badly with more social market orientated members of the Union, whose outlook was concisely put by the former French Prime Minister, and socialist, Lionel Jospin's remark, 'yes to a market economy, no to a market society'. ${ }^{13}$ The article will conclude with an examination of the extent to which the current corporate law reform proposals clearly address the collective power of corporations and are thus congruent with the development of a genuinely progressive politics as opposed to the adoption of a defensive position essentially framed by neo-liberalism and resulting in a society thoroughly infused by the values and culture of market individualism.

\section{The Rise and Demise of Collectivism}

In order to progress it is first necessary to attempt to chart the import of the notion of collective power, and corporate collective power in particular, as these ideas are central to the issues this article seeks to explore. Further, as power may for current purposes be said to be located in the temporal relations to be found within the complex matrices of agents (consisting of both institutional entities and individual persons) and structural conditions that compose society, the overall dimensions of collective power will only be rendered amenable to illumination, albeit feeble, through a broad investigation of pertinent changes in society over time. ${ }^{14}$ Hence, it will be argued that collective power is fully intelligible only in the context of the particular stage of modernity under examination and that the ambit of such power (and thus its precise significance) will be subject to modulation over time as the rationalities of modernity play out and thereby re-shape its very fabric. ${ }^{15}$ At a more concrete level the analysis will be pursued through the ideas of combination and especially of collectivism (which became the dominant mode of thinking in the latter part of the nineteenth century). ${ }^{16}$ In

knowledge-based economy in the world, capable of sustainable economic growth with more and better jobs and greater social cohesion, and respect for the environment.

13 See further, L. Jospin, Modern Socialism (1999). Like Blair, Jospin also places his justification for social democracy upon values, but the emphasis is quite different and is explicitly orientated around the regulation of the so-called 'natural' capitalist model (ibid., p.10).

14 That such developments are believed to occur should not be taken as an endorsement of a Whiggish or Hegelian approach to history as a progressive unfolding of events.

15 There is not space here to pursue the thorny conceptual issues raised by the notion of post-modernism: for a brief discussion see K. Kumar, From Post-Industrial to Post-Modern Society (1995) 137-142, 173-183, and D. Harvey, The Condition of Postmodernity (1990) chap.6. The stance that will be taken in this article is that the current environment is one variously described as high modernity (Anthony Giddens), reflexive or second modernity (Ulrich Beck), or liquid modernity (Zygmunt Bauman); and which presents certain new conditions (which only Bauman would be likely to describe formally as post-modern) of necessity entailing a critical interrogation of its own rationalities.

16 Combination remained the dominant term in the United States but in the context of corporate consolidations such as the Standard Oil Trust, industrial concentration in the United Kingdom in general tended to occur significantly later: see respectively, M. J. Sklar, The Corporate Reconstruction of American Capitalism 
line with the broader argument herein it is no coincidence that both of these concepts are more usually associated with the rise of organised labour for the collective nature of corporate power was seemingly early suppressed by the rise of a strong doctrine of separate corporate personality. ${ }^{17}$

For the celebrated constitutional lawyer Albert Dicey the growth of collectivism (admittedly largely focused around the recognition of trades unions and the enactment of social legislation) was to provide the key to his analysis of the relationship between the course of English thought and the development of English law during the nineteenth century and early twentieth centuries. ${ }^{18}$ However, despite the centrality of the concept of collectivism to his deliberations Dicey was at pains to confess that a precise definition of the term was not possible given its relative novelty and inherent ambiguity. ${ }^{19}$ Nevertheless, his stated preference was that collectivism consisted of two moments: a negative rebuttal of laissez-faire individualism as the basis for sound legislation and a positive endorsement of State intervention in order to benefit the mass of the population, even if this involved restrictions upon individual liberties. ${ }^{20}$ Unfortunately, from the point of view of clarity, the second element is one that Dicey conflated with socialism, even though he expressly rejected any application of the concomitant economic precepts to his concept of collectivism, instead reiterating his own compass for the term, whereby it was to be '... used as a convenient antithesis to individualism in the field of legislation. ${ }^{21}$

As Dicey himself acknowledged, the above definition was placed at an unhelpfully high degree of abstraction and for the purposes of this essay much may be gleaned from a close analysis of his application of the principle to concrete legislative situations. It is at this level of exposition that power relations are rendered discernible, though it should be borne in mind that Dicey was not directing his thoughts towards making different sites of collective power legible. Nevertheless, a rare explicit reference to collective power is made where the powerlessness of an individual worker against a corporation is advanced as part of the rationale for the emergent preference for collective action in English society. ${ }^{22}$ Significantly, however, the remainder of the discussion on this issue focuses around the legislative

1890-1916 (1988) and L. Hannah, The Rise of the Corporate Economy ( $2^{\text {nd }}$ ed. 1983).

17 Until the mid-nineteenth century a company was referred to in the plural reflecting the combination of its shareholders but this linguistic practice changed to the singular when shares became fully autonomous tradeable property. The adoption of a robust legal concept of separate corporate personality from the 1860's is thus best seen as a reflection of this reification of the joint stock fund into money capital, see P. Ireland, 'Capitalism Without the Capitalist: the Joint Stock Company Share and the Emergence of the Modern Doctrine of Separate Corporate Personality' (1996) 17 Journal of Legal History 41.

18 A. V. Dicey, Lectures on the Relation Between Law \& Public Opinion in England During the Nineteenth Century ( $2^{\text {nd }}$ ed., 1962; first published 1905). Dicey set out three broad periods of development: Old Toryism/ Legislative Quiescence (18001830); Benthamism/ Individualism (1825-1870); and Collectivism (1865-1900).

19 ibid., p.64, n.1, and p.67.

20 ibid., p.259.

21 ibid., p.64, n.1.

22 ibid., p.266. 
mechanisms employed in the operationalization of the collective power of workers through the legitimation of trades unions ${ }^{23}$ and no further consideration is given to the counterpoising power of the company.

This silence in relation to corporate collective power is despite the fact that Dicey had earlier deliberated upon the characteristics of modern commerce in the course of his discussion of the growth of collectivism. ${ }^{24}$ Although the relevant section of the text is perhaps not as focused as now might be desired in the light of modern developments in company law, ${ }^{25}$ Dicey's main conclusion was that through legislative development, '. . . combination has gradually become the soul of modern commercial systems'. ${ }^{26}$ Further, and in accordance with his general typology of collectivism, this 'revolution' in thought (to use Dicey's own term) had encouraged the State to interfere (on a constant basis) with individuals' private property rights in furtherance of business ends ${ }^{27}$ and had also resulted in a tendency to celebrate the advantages of collective action and thereby to diminish the importance of individual endeavour. ${ }^{28}$ It would seem that Dicey (perhaps unwittingly) had thus introduced another strand of meaning within his concept of collectivism by which it refers to the agency and collective power of a corporate body as a result of the combination of its shareholders and its legal and organisational structure. ${ }^{29}$

23 Dicey believed that legislative impulses leading to the enactment of Combination Acts in 1800, 1825 and 1875 exemplified his three stages of development. See ibid., pp.271-73 and n.18 above.

24 ibid., pp.245-248.

25 It would be unfair to blame Dicey for his lack of clarity of exposition regarding uses of the corporate form and the precise site of agency within a company as the 'one man' private company had only just been endorsed by the House of Lords in Salomon v A. Salomon \& Co Ltd [1897] A.C. 22, and the relationship between the shareholders and the board of directors over management matters was still the subject of intense dispute until the decision, in the latter's favour, of the Court of Appeal in Automatic Self-Cleansing Filter Syndicate Co Ltd v Cuninghame [1906] 2 Ch. 34.

26 Principally the Limited Liability Act 1855 and Joint Stock Companies Act 1856 as consolidated by the Companies Act 1862. For an extended discussion of nineteenth century developments in company law from a doctrinal and a sociopolitical view see respectively, B. C. Hunt, The Development of the Business Corporation in England 1800-1867 (1936) and T. L. Alborn, Conceiving Companies: Joint-stock Politics in Victorian England (1998).

27 Dicey contrasts a sole proprietor with a railway company having monopoly privileges and requiring compulsory purchase rights. The special facets of the latter are held to tie it closely to the state and to suggest public ownership. The relation between the corporation and state was a matter of considerable contemporary theoretical debate: see, e.g. F. Hallis, Corporate Personality (1930).

28 Dicey, op. cit., n.18, p.246, n.2 and p.247.

29 See n.25 above. The nature of combination is not explored but the rise of managerialism due to the dispersed nature of personal shareholdings and the subsequent shift from personal to impersonal shareholding resulting in, 'a polyarchic structure of hegemonic financial intermediaries which participate in the controlling constellations of . . . major enterprises' were well in the future: see further, J. Scott, Corporations, Classes and Capitalism (2 ${ }^{\text {nd }}$ ed., 1985) (quotation at p.259). 
History can make for surprising bedfellows and for Karl Marx, also commentating on the growth of joint-stock companies in the mid-nineteenth century (albeit from a very different political and theoretical perspective), there was no doubt that capital possessed this element of social power. Indeed, it was for this very reason that the joint-stock company represented the very negation of the private entrepreneurial capitalist ${ }^{30}$ and thereby amounted to ' $[\mathrm{t}]$ he abolition of the capitalist mode of production within the capitalist mode of production itself', being in essence '.. . private production unchecked by private ownership. ${ }^{31}$

Marx was, of course, discussing the role of credit and joint-stock companies in the wider context of his analysis of society in the early stages of capitalist development. According to Marxist theory the motor of capitalism lay in its insatiable desire for accumulation through the medium of exchange on the market and its fuel lay in the commodification of the labour relationship between the owners and workers. The bourgeoisie were thus in a class war with the proletariat and this antagonism was the hallmark of such a thoroughgoing change in society that Marx and Engels discerned a significant discontinuity with the past:

"Constant revolutionizing of production, uninterrupted disturbance of all social conditions, everlasting uncertainty and agitation distinguish the bourgeois epoch from all earlier ones. All fixed, fast-frozen relations, with their train of ancient and venerable prejudices and opinions, are swept away, all newformed ones become antiquated before they can ossify. All that is solid melts into air ... " 32

Building upon this famous metaphor, Zygmunt Bauman has described the development of this stage of modernity as one whereby, ' $[t]$ he melting of solids lead to the progressive untying of economy from its traditional political, ethical and cultural entanglements ... [and thereby] ... sedimented a new order, defined primarily in economic terms. ${ }^{33}$ The foremost casualty

30 A view shared by Joseph Schumpeter, though for reasons aligned with Dicey rather than Marx, in that he believed that the modern corporation 'relentlessly narrows the scope of capitalist motivation': J. Schumpeter, Capitalism, Socialism and Democracy (1994, first published 1943) 156.

31 K. Marx, Capital: A Critique of Political Economy Vol. III (1981) chap.27, and p.569. This is not a proposition which would be recognised by economic liberals for whom the recognition of shares as a form of private property has significant governance implications: see, e.g. E. Sternberg, Corporate Governance: Accountability in the Marketplace ( $2^{\text {nd }}$ ed., 2004). However, this view of shareholding would seem untenable, certainly in large publicly traded companies: see further, P. Ireland, 'Company Law and the Myth of Shareholder Ownership' (1999) 62 M.L.R. 32 and J. Parkinson, Corporate Power and Responsibility (1993) $32-41$.

32 K. Marx and F. Engels, The Communist Manifesto (1998) 38. For an incisive account of the relationship between this text and modernity see M. Berman, All that is Solid Melts Into Air: The Experience of Modernity (1983) Part II.

33 Z. Bauman, Liquid Modernity (2000) 4 (hereafter 'Liquid Modernity'). The following account draws heavily upon Bauman's analysis in this work (especially the foreword and chapters 1,2 and 4) and also upon the related essays in Z Bauman, The Individualized Society (2001). Many of the issues raised are the 
of this dissolution was the conception of being born into a place and status which essentially determined an individual's subsequent life-course through the interaction of a dense constellation of traditional cultural norms and customary practices. The emergence of a capitalist order thus generated new possibilities for individuals but the price was that it simultaneously, 'left the whole complex network of social relations unstuck - bare, unprotected, unarmed and exposed, impotent to resist the business-inspired rules of action and business shaped criteria of rationality, let alone to compete with them effectively.' ${ }^{34}$ The economic logic of the process, however, initially resulted in the evolution of a stabilisation mechanism by which the freedom imposed upon individuals by the decline of tradition was directed through the construction of distinct class and gender roles that managed expectations and re-constrained action. In this manner these constructs provided a means by which the old solids could be replaced by new solids which could reasonably be expected to be durable in a world of radical and rapid transformation; such new solids thereby constituting a regime (to use Bauman's phraseology) of heavy capitalism or solid modernity. ${ }^{35}$

An undoubted iconic symbol of heavy capitalism is to be found in the mass production system of the Fordist factory, as exemplified by Henry Ford's plant at Highland Park in San Francisco. ${ }^{36}$ It embodies all the key features of solid modernity, viz: the utilization of large centralized organizations governed by instrumental rationality ${ }^{37}$ and directed towards mass production utilising economies of scale requiring considerable investment in heavy plant with assembly lines populated by a whole host of labourers each undertaking a discrete largely de-skilled operation in a production process orientated around Taylorist principles. ${ }^{38}$ The primary emphasis is thus upon permanence and structure and the result is a prison that neither capital nor labour is able to leave. ${ }^{39}$

subject of considerable contention and the principal areas of disputation will be highlighted here or in the later discussion of post-Fordism.

34 Liquid Modernity, p.4.

35 Such change was very thorough-going; time itself was restructured to fit with the regularities industrial production required, see E. P. Thompson, 'Time, WorkDiscipline and Industrial Capitalism' (1967) 38 Past and Present 56.

36 For introductions to Fordism see P. Brown and H. Lauder, Capitalism and Social Progress (2001) chap. 3 and D. Harvey, The Condition of Postmodernity (1990) chap. 8. The acme of this line of thinking may perhaps be found in J. K. Galbraith's concept of the technostructure (with its intimate relationship to the large corporation) in The New Industrial State (2 $2^{\text {nd }}$ ed., 1991).

37 Given the planning and co-ordination problems Fordism entailed it is unsurprising that bureaucracy is strongly associated with it. For a nuanced defence of the 'ethos of office' against both philosophical and managerialist critiques see P. Du Gay, In Praise of Bureaucracy (2000).

38 F. W. Taylor, Principles of Scientific Management (1947, first published 1911). Taylor's primary aim was to increase productivity by reducing 'soldiering' (deliberate slacking); efficiency was maximized by detailed time and motion studies which removed discretion from employees in the execution of their work. Taylor himself maintained a rather utopian vision of his project as he believed the resultant gains would be so plentiful as to ensure a co-operative approach within the workplace and thus obviate the need for unions or collective bargaining: see ibid., Testimony Before the Special House Committee in 1912.

39 Liquid Modernity, p.145. 
In this environment capital and workers were thus locked together in a mutual interdependency based upon the economics of mass production, whereby the concentration of capital within large corporations was to a large extent mirrored by the agglomeration of workers needed to operate the plant. Within this seemingly permanent framework of long-term relations it made rational sense for the workers to act together so as to improve their common future lot by combining so as to exercise a countervailing collective power to that of capital. ${ }^{40}$ Further, the movement of people into cities to feed the industrial maw created a problem of order and thus the state also became increasingly enmeshed into the equation. In this light, the subsequent adoption of Keynesian inspired economic policy and the construction of the welfare state, as the principal elements of the post-war settlement, were by no means coincidental as the state could use these stabilising capacities to avoid or at least ameliorate the consequences of the periodic crises or cyclical downturns in the economy. Hence, a protean and rather loose corporatist approach emerged, albeit bounded within the clear parameters of a national economy and society, as a means of seeking to encourage both growth and stability. ${ }^{41}$

However, as the aforementioned quote from The Communist Manifesto clearly indicates, the dynamics of capitalism are relentless and despite the formidable institutional edifices assembled it proved impossible to maintain the Keynesian-Fordist regime. Instead, through the rise of an informational society ${ }^{42}$ and the concomitant processes of globalization national boundaries have been rendered evermore permeable and collective ties have been considerably weakened. In contrast to the regimented and predictable world of heavy capitalism instantaneous information flows and borderless competition have generated a paramount need for speed and flexibility: in this world of short-term horizons modernity has been rendered liquid and capitalism light. ${ }^{43}$

For Bauman there appear to be two central characteristics of light capitalism: first, power is exercised foremost by mobility, and secondly, people are subjected to radical 'individualization'. As the combination of these ideas has profound consequences for the notion of collectivism here under examination it is proposed to analyse them in some detail. By 'individualization' Bauman refers to the fact that individuals living under present conditions have no given identities, (traditionally ascribed roles having been stripped away in the acid bath of modernity) and are, therefore,

40 ibid., p.33.

41 Clearly the United Kingdom has never come close to developing a truly corporatist system; the high-water mark was reached with the publication of the ill-fated Bullock Report: Committee of Inquiry on Industrial Democracy (1977; Cmnd. 6706). For a well contextualized account of company law in this period see T. Hadden, Company Law and Capitalism (2 $2^{\text {nd }}$ ed., 1977), especially Parts I and III.

42 The term refers to a society permeated by new information technologies which are themselves pivotal sources of productivity and power, see further M. Castells, The Rise of the Network Society ( $2^{\text {nd }}$ ed., 2000) 21, n.31.

43 Bauman respectively equates the period of solid modernity with heavy capitalism and liquid modernity with light capitalism, e.g. Liquid Modernity, p.145 and p.167. 
forced to construct them for themselves. ${ }^{44}$ Of course, being inherent to modernity, individualization was a feature of heavy modernity too, but crucially the surrogates of class and gender that served as frames for personal and collective identity orientation during the Fordist period are no longer straightforwardly available under the regime of liquid modernity. ${ }^{45}$ The reasons for this are complex, but in essence it would seem that the premium currently placed on flexibility leads to high degrees of uncertainty, low levels of trust and a focus on short-term engagements. These factors, in turn, reduce the ability to have a secure and comprehensive, as opposed to provisional and partial, grasp of the present and thus render any strong teleological view of societal progression incoherent. Hence, in stark contradistinction to Dicey merely a century earlier, it is Bauman's view that, '[t]hough the idea of improvement ... through the legislative action of society as a whole has not been completely abandoned the emphasis (together with importantly the burden of responsibility) has shifted decisively towards the self-assertion of the individual. ${ }^{\prime 4}$

Further, the demise of collectivism is compounded by the onerous nature of the responsibility placed upon each individual and the unequal allocation of resources to perform the task. As Bauman notes:

"[t]he task of self-identification has sharply disruptive side effects. It becomes the focus of conflicts and triggers mutually incompatible drives. Since the task shared by all has to be performed by each under sharply different conditions, it divides human situations and prompts cut-throat competition rather than unifying a human condition inclined to generate cooperation and solidarity." 47

However, even as the possibilities of collective action for labour seem to be receding, as it becomes ever more difficult for individuals' interests to cohere, it is also the case that labour is simultaneously losing out in the dimension of power. The reason for this is that labour has largely remained bound to particular local geographical territory whilst capital alone has broken free of the previously binding relationships that constituted the matrix of solid modernity and attained unprecedented mobility within the deregulated flows of the global marketplace. ${ }^{48}$ As power in the context of liquid modernity lies in the ability to disengage even the threat of withdrawal based

44 The concept is thus quite different to laissez-faire individualism; see also U. Beck and E. Beck-Gernsheim, Individualization (2002) preface xxi, and 202.

45 For Beck class in second modernity is indeed reduced to a zombie category, ibid., p. 206. Less radically, a recent historical study has discerned three basic models of class (labelled hierarchical, tripartite and dichotomous respectively) which intersect and operate simultaneously in the contemporary British consciousness but nevertheless concludes that whilst class continues to have significance this is not primarily as a mobilizing collective force: see further D. Cannadine, Class in Britain (2000).

46 Liquid Modernity, p.29.

47 ibid., p.90, and see also p.35. Truly, to use Milan Kundera's phrase, an 'unbearable lightness of being'.

48 This is certainly true of the global financial markets but is taken by many commentators to apply equally to transnational corporations, see e.g. G. Soros, George Soros On Globalization (2002) 1. 
upon the real potential to do so creates a powerful bargaining chip for capital against both workers and state. Capital flight is thus one of the principal organising features of light capitalism and the resultant accommodation of the expanded market its accompanying leitmotif. ${ }^{49}$

Further, even the requirements of greater flexibility demanded by the regime of light capitalism do not appear to have undercut the resilience of the large corporation by breaking the huge monoliths that populated the Fordist landscape into more nimble small and medium enterprises as some commentators had predicted. ${ }^{50}$ Hence, the demise of collectivism has impacted differentially upon the Fordist trinity by re-configuring the bounds of the market and public space, very crudely: workers are individualized; the state loses many of its substantive directive capacities and increasingly undertakes an enabling role; and companies seem increasingly powerful as institutional repositories of collective resources ${ }^{51}$ subject principally to a market discipline in any event closely aligned with the rationalities and values underlying their own constitution. ${ }^{52}$

\section{Individualism Re-born: Thatcherism and the Neo-Liberal Heritage}

In order to better understand the way in which companies are conceptualised within the territory of light capitalism it is also necessary to trace the development of the intellectual currents opposed to collectivism during the twentieth century and Dicey once again provides a good point for departure. At the outset of the twentieth century Dicey was already nostalgic for the days of Benthamite liberal individualism (which had been in its pomp some forty years before), even though he was self-consciously writing his analysis of the growth of the collectivism when that expansion was yet to reach its zenith - his preface to the second edition of Law and Public Opinion in England (published in 1914) indicates his awareness that the corporate entity, trades unions and the state itself were all still expanding both their size and capacities. Indeed, it was perhaps due to the relatively nascent development of collectivism and his acknowledgement that some social reform was necessary that Dicey's outlook as a committed liberal individualist was manifested only by a general wistful tone and occasional

49 The reality of capital flight is a matter of considerable contention; Bauman adopts a hyperglobalist stance with little qualification: Liquid Modernity, pp.149-150. Commentators more sceptical of globalization view companies as less likely to seek extraterritoriality and nation states as retaining greater capacities: see, e.g. P. Hirst and G. Thompson, Globalization in Question (2 ${ }^{\text {nd }}$ ed., 1999) chap. 8.

50 For a brief discussion see Castells, op. cit., n.42, pp.167-8.

51 In the field of economic regulation, where substantial organizations (including the state and state agencies) bargain amongst themselves in 'regulatory space', this facet has made the large company both a very important and, given that by virtue of its functions it transcends the conventional public-private divide, also a unique player. See further, L. Hancher and M. Moran eds., Capitalism, Culture, and Economic Regulation (1989) chap. 10, and especially 272 and 274-5.

52 This is not to suggest that economic efficiency is necessarily the principal driver behind the development of the large company: for alternative political and organizational accounts see respectively, W. G. Roy, Socializing Capital: The Rise of the Large Industrial Corporation in America (1997) and C. Perrow, Organizing America: Wealth Power and the Origins of Corporate Capitalism (2002). 
warnings as to the consequences of the collective principle if worked through to its logical conclusion.

However, by 1944, when Friedrich Hayek published The Road to Serfdom, the appeal to individualism had become much more passionate and urgent as collectivism was much more firmly entrenched and indeed the liberal influence of writers such as Dicey had waned to an extent that caused Hayek to lament that such figures once '. . . admired in the world at large as outstanding examples of the political wisdom of liberal England, are to the present generation largely obsolete Victorians. ${ }^{53}$ For Hayek, writing against a background of the totalitarian regimes of Nationalism Socialism in Germany and Stalinist Marxist Leninism in the USSR, this generational change in outlook was most regrettable, as it was the dangers of collectivism (particularly the threat to individual freedom highlighted by the like of Dicey) which were now all too apparent.

Although the precise definition of the concept of collectivism was problematic for Hayek, as was the case for Dicey, it is clearly focused upon socialism and the centralised control of the economy by the state. ${ }^{54}$ In Hayek's view at a technical level planning on this basis was doomed to inefficiency on epistemological grounds as the state was incapable of collating the information required, and at a moral level such co-ordination was wrong as it was imposed upon individuals regardless of their own values and desires. ${ }^{55}$ Ultimately there was thus a stark moral choice to be made in selecting a method of economic co-ordination between the paths of freedom and coercion: liberalism gave priority to the former and collectivism inevitably resulted in the latter. For Hayek the key policy prescription to preserve individual liberty was thus to maximise use of the spontaneous forces of society and to resort as little as possible to coercion. However, although economic co-ordination was to be provided primarily by the spontaneous workings of the free market, Hayek repeatedly rejected a dogmatic laissez-faire stance and indicated that the state does have a role (albeit relatively minimal) particularly in maintaining an effective legal system and preserving competition. ${ }^{56}$

The political facts then underlying world events meant that Hayek's principal argument was directed to the relation between the state and individual and, whilst this axis brought the market to the fore, it did not have great deal to say about the significance of the corporate entity. Further, the collective

53 F. A. Hayek, The Road to Serfdom (1997, first published 1944) 136. It is not possible in this context to examine the rich vein of work Hayek subsequently produced, notably The Constitution of Liberty (1960) and Law, Legislation and Liberty (1993). For a most insightful survey and critique of Hayek's oeuvre see J. Gray, Hayek on Liberty ( $3^{\text {rd }}$ ed., 1998).

54 The problem is of quite a different order to that posed by Dicey; see Hayek, The Road to Serfdom, pp.24-26.

55 The two strands are intimately related given Hayek's belief that knowledge is tacit and, therefore, local.

56 E.g. ibid., pp.27-29 and p.60. Whilst here both of these functions are seemingly conceived in part as self-consciously creative acts by the state, in later writings Hayek seems to suggest an application of the principle of spontaneous order to the constitution of the institutional fabric itself: for a brief commentary see Gray, op. cit., n.53, p.70. 
effort and technological progress evidenced during the war stimulated an expansive and optimistic view of state action and Hayek's ideas thus fell on largely stony ground. ${ }^{57}$ In addition, Hayek's views in The Road to Serfdom were perhaps somewhat negatively expressed. ${ }^{58}$ It fell to Milton Friedman, some twenty years later, to place the populist liberal economic argument concerning competitive capitalism in a more celebratory mode, with the publication of Capitalism and Freedom in 1962.59 Friedman explicitly aligned himself to the tradition of Dicey and Hayek and consequently also sought to restrict the ambit of the state and to maximise the freedom of the individual through the mechanism of market exchange. In Freidman's view contracts determined in a free market provided the optimal level of coordination without resort to coercion as it is the case that, '.. both parties to an economic transaction benefit from it, provided the transaction is bilaterally voluntary and informed. ${ }^{60}$ The role of the state was, in similar vein to Hayek, to establish and enforce the legal framework, to act paternalistically in the rare case of mental incapacity and to intervene in cases of monopoly.

The discussion of monopoly power is central to Friedman's exposition of competitive capitalism and involves an examination of the Fordist triad of corporation, labour and state. The reason that monopoly is so important within Friedman's framework is due to the fact that it removes choice with the consequent dual effects of preventing true free exchange and of rendering the monopolist's power visible, thereby leading to calls for it to be exercised in a socially responsible manner. As is well known, Friedman strongly rejects any suggestion that the agents of business (or labour) have in general any duty to act responsibly or in any way beyond that served by the pursuit of the shareholders (for unions read members) self-interest. Fortunately his survey of the extent of monopoly in the United States proved that there was little overall cause for concern in the business field and, whilst growing, the monopolistic effects of labour combination were similarly still fairly negligible: the major problem lay in government regulation through federal agencies of sectors such as agriculture and transport. ${ }^{61}$ Thus it would seem that Friedman's fundamental position, as verified by him on a general empirical level, can be accurately summarised as follows:

"The participant in a competitive market has no appreciable power to alter the terms of exchange; he is hardly visible as a separate entity; hence it is hard to argue that he has any 'social responsibility' except that which is shared by all citizens to obey the law of the land and to live according to his lights." 62

57 The 1945 general election resulted in the Labour Party achieving a landslide victory and the Atlee government proceeded to lay the foundations of the modern welfare state.

58 The title itself sets the oppositional tenor of the book and also establishes its dark and sombre tone.

59 M. Friedman, Capitalism and Freedom (1982, first published 1962).

60 ibid., p.13 (italics in original).

61 ibid., chap. VIII.

62 ibid., p.120: the parallel with Adam Smith's invisible hand is obvious, but note also Bauman's comment that, "[t]he favourite strategic principles of the powers- 
Although this is not a point that Friedman needed to elaborate upon, it would seem from his discussion of enterprises, made in the immediate textual context of the above quoted proposition, that a company would constitute such a 'virtually invisible' market participant. ${ }^{63}$ Further, this conclusion is reached despite the express consideration (admittedly made earlier and in a different context) of the application to the corporation of the conflict arising between the freedom to combine and the freedom to compete.

Dicey also made reference to this point and it is instructive to note the different ways in which these two liberal thinkers frame the issue and how the notion of collective power is much less visible and important in Friedman's analysis. For Friedman the conflict is essentially one within the market domain and concerns the possibility of a monopoly arising either through restriction of the freedom to establish an enterprise or restriction of access to the market by established participants. ${ }^{64}$ Whilst Dicey's discussion of the characteristics of modern commerce is also concerned with monopoly, ${ }^{65}$ he nevertheless situates the narrow problem at hand squarely within his conceptual opposition between collectivism and individualism. In this light the freedom to incorporate with limited liability that was finally consolidated in the Companies Act 1862 paradoxically both enhanced individual freedom and yet also simultaneously undercut it by transferring the management of business to corporate bodies, and thereby substituting 'combined for individual action' ${ }^{66}$

The work of Hayek and Friedman thus provided a set of ideas which linked economic individualism with political freedom and which elevated the market into the key institutional mechanism for 'organizing' society. By way of correlation, the state's role, together with that of the political realm generally, was to be consciously reduced by the adoption of '. . . a presumption or prejudice in favour of individual liberty, that is, of laissez faire. ${ }^{67}$ Within the market equity would be realised by formal rules of equality of opportunity (with no regard to equality of outcome) ${ }^{68}$ and, in the absence of monopoly, market actors would be treated alike with no reference to their relative substantive capacities. As Friedman himself dryly noted, such ideas were somewhat out of the mainstream given the predominant

that-be are nowadays escape, avoidance and disengagement, and their ideal condition is invisibility': Liquid Modernity, p.40.

63 This ambiguity is nevertheless unfortunate given the undoubted significance of the company within the system of competitive capitalism. Contrary to the orthodox legal understanding Friedman appears to view companies as direct instruments of their shareholders with no effective separate personality (op. cit., n.59, p.135) and private companies are on this basis directly equated with individuals in the market (ibid., p.14). The position of publicly traded companies is hard to glean but presumably they too must be regarded as normal market participants unless they have attained a monopoly position.

64 ibid., p.26.

65 Like Friedman who in most cases of technical monopoly would reluctantly opt for the least worse evil of private ownership (ibid., p.28) Dicey would seem reluctant to endorse state ownership as preferable to joint stock ownership in such circumstances, see Dicey, op. cit., n.18, pp.245-248.

66 ibid., p.246, n.2.

67 Friedman, op. cit., n.59, p.201.

68 ibid., p.195. 
Keynesian mode of thinking at height of Fordist collectivism and thus received little attention until experience changed the climate of thinking. ${ }^{69}$

The events that led to such a change are relatively easy to list (principally the oil shocks, high inflation, and industrial conflict of the 1970s and the nascent technological and cultural changes of that decade, which would lead to an intensification of competition in the global market, together with an increasing emphasis on consumption as opposed to production) but notoriously difficult to analyse, particularly as to causality, given the number of inter-related processes. ${ }^{70}$ Further, whilst many companies have employed lean just-in-time production and sought niche markets, it is clear that elements of Fordist mass production still remain, even if production is more automated and companies more downsized and delayered. Nonetheless, whether the new environment is labelled as a regime of flexible accumulation, ${ }^{71}$ disorganized capitalism, ${ }^{72}$ light capitalism or post-Fordism, ${ }^{73}$ one common feature is an acknowledgement of the decline of the economic nationalism that was at the core of the Keynesian-Fordist state and by implication of the unmediated directive capacities of the state itself.

The times were thus propitious for the Thatcherite 'project', which celebrated the individual and the market, and was explicitly both anti-statist and anti-collectivist (at least in relation to trades unions) in outlook. Whilst there is considerable debate as to extent that Thatcherism was conceived from the outset as coherent political project and to which it completely reflected the emerging environment as opposed to seizing upon certain elements of it, there is no doubt that it resulted in the "establishment of a neoliberal economic and political agenda as the dominant paradigm to characterise British politics.' ${ }^{74}$ Thatcherism drew heavily upon both Hayek and Friedman in order to provide a theoretical underpinning for the retreat of the corporatist state and the ascension of the market. As is well known, this required the nurturing of an enterprise culture that extended beyond the formal economy and required the construction of rugged individuals motivated by self-interest and capable of exploiting opportunities in a dynamic economy. The enterprise culture and the market-individualism it demanded was thus '. . . at the very heart of the Government's moral crusade.' 75

69 ibid., 1982 Preface.

70 See A. Amin ed., post-Fordism- A Reader (1994). In his introductory chapter Amin indicates the dispute as to the very existence of the transition and discusses three of the leading post-Fordist models, viz: the regulation school, the neoSchumpeterian school and the flexible specialization school.

71 Harvey, op. cit., n.36, Part II.

72 S. Lash and J. Urry, The End of Organized Capitalism (1987).

73 For accessible overviews see, Brown and Lauder, op. cit., n.36, Part II, and A. Stewart, Theories of Power and Domination (2001) chaps. 3 and 4.

74 For a subtle analysis, see R. Heffernan, New Labour and Thatcherism (2001) chaps. 3 and 4 (quotation p.60).

75 See P. Heelas and P. Morris eds., The Values of the Enterprise Culture (1992) (quotation p.1) for an excellent set of critiques. Chapter 2 of this work also contains a short discussion of the enterprise culture by one of its chief progenitors, Lord Young. 
The pursuit of this objective led to some deep paradoxes, for, as discussed above, the essential dynamism of the capitalist process is such as to place societal authority, coherence and stability in constant question due to the new freedoms it undoubtedly generates. Hence, a strong state is required in order to make appropriate regulatory interventions. By way of illustration, markets in complex societies require to be structured in such a way as to ensure their visible probity, so as to maintain confidence in their operation. An excellent example of this is given by Bruce Carruthers and Terence Halliday in their study of the regulation of the insolvency market by the Thatcher government. The mode of governance adopted essentially involved licensing a monopoly position to a newly created profession of insolvency practitioners. Whilst this would on general policy grounds have been a complete anathema, it was here a necessary evil, allowing an indirect extension of the state's power of surveillance into a private market through the reporting obligations placed upon the profession. Contrary to neo-liberal theory, in the cold light of reality markets do not therefore spontaneously emerge but require to be actively constituted for ' $[\mathrm{t}]$ he legitimation of markets, and the provision of normative foundations, is substantially a political problem. ${ }^{76}$

In addition, the intensification and greater permeation of market operations within society and the expansion of market processes and attitudes that an enterprise culture entailed generated a deeper paradox, for as Stefan Breuer has noted, '[m]arket societalization means an increase in interdependency and the atomization of the social, the increasing density and the negation of all ties - asocial sociability. ${ }^{\prime 77}$ In this climate the outcome of competitive market processes was thus more likely to produce an aggressive market individualism focused around calculative behaviour, unrestrained egoism, ambition and excessive consumption than the more restrained Victorian virtues of prudence, thrift and respectability that many Thatcherites espoused. A further facet of the 'asocial sociability' underlying market individualism derives from the principal theoretical basis the Thatcherites adopted, for '[n] eoliberal economics rests upon an image of the autarkic human self. It assumes that individuals alone can master the whole of their lives, that they derive and renew their capacity for action within themselves. $^{78}$ Accordingly, for Thatcherites the avowed belief in the justice of market outcomes as the result of a non-coercive process thus enabled considerable moral responsibility to be placed upon the individual for any setbacks: failure was due to a lack of personal effort or enterprise. Such an all encompassing view of market relations led to a further paradox, for (being morally neutral as to outcome) the market is itself incapable of generating

76 T. C. Halliday and B.G. Carruthers, 'The Moral Regulation of Markets: Professions, Privatization and the English Insolvency Act 1986' (1996) 21 Accounting, Organizations and Society 371,373 . The ramifications of this are far reaching for as Campbell (who strongly endorses the value of market arrangements) states, '[t] $]$ he private, as a category in itself, does not exist, for the private is a public construction, the limits of which are then a matter of public debate': D. Campbell, 'The Hybrid Contract and the Merging of the Public and Private Law of the Allocation of Economic Goods' in D. Campbell and N.D. Lewis eds., Promoting Participation: Law or Politics? (1999) 68.

77 S. Breuer, 'The Denouements of Civilisation: Elias and Modernity' (1991) 128 International Social Science Journal 401, 407.

78 Beck and Beck-Gernsheim, op. cit., n.44, preface xii. 
the underpinning values and norms upon which its very operation depends. Further, the social cohesion necessary to undertake this task is particularly hard to build if individuals are regarded as entirely self-sufficient (which in any event is obviously empirically problematic) as "trust is far more likely to flourish in a society whose members openly acknowledge their interdependencies and vulnerabilities and build their ethic of fairness around this realization.' 79

In the light of the above, and the central paradox that the Thatcherites embraced a radical view of market relations whilst simultaneously seeking to maintain traditional values and gender roles, it is unsurprising that there was a resort to 'authoritarian populism' 80 in order to maintain social stability. However, whilst the state thus needed to be strong, it was also undoubtedly re-configured to a more enabling role, and corporatism and trades union collectivism were effectively swept away in accordance with Hayek's precepts that,

". . . the real exploiters in our present society are not egoistic capitalists or entrepreneurs, and in fact not separate individuals, but organizations which derive their power from the moral support of collective action ... More real injustice is probably done in the name of group loyalty than from any selfish motives." 81

The ground was thus cleared for the market, and most importantly the values embodied in the market individual, to hold sway: for as Lady Thatcher herself made clear whilst, "[e]conomics are the method: the object is to change the soul. ${ }^{\prime 2}$ At the same time the collective power of the corporation was rendered invisible as the company was seemingly absorbed as just one other actor into the anonymity of the market process. ${ }^{83}$

\section{'New Times' and New Labour}

The demise of collectivism, as exemplified by organised labour and the Keynesian Fordist state, together with the radical re-vivification of the individual as a homo economicus in the Thatcherite neo-liberal mould has placed a great deal of expectation upon the market as an institutional tool and a corresponding pressure on individuals to adopt an entrepreneurial self, for as David Jenkins has put it '[a] useful modus operandi has been overpromoted into being an inevitable modus vivendi. ${ }^{94}$ However, New

79 L.E. Mitchell, Stacked Deck: A Story of Selfishness in America (1998), especially chap. 10 (quotation p. 208). See also M. A. Fineman, The Autonomy Myth (2004) urging collective responsibility in the family sphere as an acknowledgement of universal dependency.

80 For general critiques see: S. Hall and M. Jacques eds., The Politics of Thatcherism (1983) (quotation p.10); Giddens, Beyond Left and Right (1994) chap. 1; J. Gray, False Dawn (1999) 24-28; and D. Marquand, Decline of the Public (2004) chap. 4.

81 Hayek, Law, Legislation and Liberty (1993) Vol. 3, 96.

82 The Sunday Times, 7 May 1988.

83 Hayek's later views are most instructive here, for although he identifies organizational power as both important and undesirable (due to its essentially coercive nature), he is most reluctant to apply his analysis to the company as opposed to the trade union, see op. cit., n.81, chap.15.

84 D. Jenkins, Market Whys and Human Wherefores (2000) 114. 
Labour has not relieved this pressure on individuals nor refuted the need for markets, as both are deemed inescapable if Britain is to be competitive in the dynamic, globalized world economy: in Gordon Brown's words '. . . our mission must be relentless: to strengthen markets, to maximise efficiency.' ${ }^{85}$ Hence, traditional Labour demand management policies have been discarded $^{86}$ in favour of supply-side interventions (which in Brown's view actively constitute growth according to neo-classical endogenous growth theory) in order to support a culture of enterprise and the structural flexibility required within a modern knowledge economy. The role of the state in the economy has thus been re-modulated, for, as Alan Finlayson has noted, whilst '. . . dogma driven neo-liberals sought to liberate the market from the state, New Labour seeks to deploy that state in the name of the market because it sees that the nature of the market has changed. ${ }^{87}$ In this sense New Labour has both adopted and adapted the inherited Thatcherite terrain. ${ }^{88}$

However, in contrast to Thatcherism, New Labour's vision of the world is not primarily ideological for,

“. . . New Labour does not formulate political ideas on the basis of a substantial moral claim about the nature of society and the distribution of its resources. It does so on the basis of a 'sociological' claim about the novel condition of contemporary society; a belief that the world has been transformed, while our political ideas have not kept up pace ... [Thus] [p]olicy is legitimated not by ethical principles but by the truth of certain social facts ..." 89

Finlayson identifies that two key influences on New Labour in determining the relevant social facts are the analysis of Thatcherism and post-Fordism given at the end of the 1980s in the 'New Times' 90 and the work of Anthony Giddens. The New Times analysis by leading Marxists sought to develop ideas for the left in response to 'epochal change' and roughly comprised two broad strands of thinking, one organisational and the other ideological, but

85 Speech to the Social Market Foundation (3 February 2003). Whilst this speech contains a far reaching analysis of the role of markets, including the views of critics on their moral limitations, the fundamental message is accurately conveyed by the quotation. For a good summary of the present New Labour stance see the election speeches of Blair (Canary Wharf, 14 April 2005) and Brown (London Business School, 27 April 2005). For a comprehensive account of the New Labour project see S. Driver and L. Martell, New Labour: Politics after Thatcherism (1998) and Blair's Britain (2002).

86 Such policies are perceived as infeasible in any event due to the electoral implications of taxation. A point presciently noted by Dicey as being likely to arrest collectivist growth: op. cit., n.18, p.302, n.1.

87 A. Finlayson, 'New Labour: the Culture of Government and the Government of Culture' in T. Bewes and J. Gilbert eds., Cultural Capitalism: Politics after New Labour (2000) 177, 186.

88 The post-Thatcherite label should not disguise fundamental differences particularly over social welfare and cohesion; see Driver and Martell (1998), op. cit., n. 85 , chaps.5 and 6 .

89 A. Finlayson, 'Third Way Theory' (1999) 70 (3) The Political Quarterly 271, 271.

90 Hall and Jacques eds., New Times: The Changing Face of Politics in the 1990's (1989). 
both based on the wider cultural understanding of political economy that emerged in the Thatcherite period.

The organizational thread ${ }^{91}$ has been the most influential and received an undoubted boost due to the exponential growth in information technology that has occurred since the early 1990s combined with an increasing awareness of the processes of globalization. Indeed, the need for flexibility and entrepreneurship in order to compete in a relentlessly dynamic global market driven by the knowledge economy and organized through open-ended networks has become a New Labour mantra. ${ }^{92}$ Whilst market individualism was thus embraced, albeit for practical as opposed to ideological purposes, New Labour was not blind to the problems of social cohesion that beset the Thatcherite years and the difficulties that rampant individualism had caused for the very sustenance of effective markets. Thus in order to socialise the market individualist, Blair first focused upon the concept of stakeholding, ${ }^{93}$ which, as initially conceived, was a radical concept with application in the spheres of economy, society and politics.

An alternative approach to integrating the individual with society had already been offered by the ideological strand of the New Times which had analysed the rise in consumption and freedom associated with markets (in conjunction with the decline of collective solidarities) as opening up new ground for a radical politics of identity. ${ }^{94}$ Such a politics would seek both to celebrate difference and diversity and to highlight their significance as hitherto neglected sites of conflict and power. In this respect there was a clear resonance with stakeholding, which, at the very least, operated by seeking to identify certain interests with particular individuals or groups and allowing for the pluralist representation of these interests. It would seem that this 'constitutionalized' conflictual element was the key conceptual problem with both ideas for New Labour, as the meta-picture of society that it was seeking to present was based on a fundamental identity of individual interest ${ }^{95}$ framed by a globalization discourse of economic inevitability. ${ }^{96}$ This approach is perhaps best illustrated by the New Labour account of social justice and wealth creation, which reconciles the traditional tension between

91 ibid., see, e.g. the contributions by J. Urry and C. Leadbeater.

92 The exhilaration of light capitalism and the inevitable burden of individualization are well brought out in the titles to the principal works of the leading guru: see C. Leadbeater, Living on Thin Air (1999), and Up the Down Escalator (2002). A similar analysis has also been undertaken in the U.S.: see R. Reich, The Work of Nations (1993), and The Future of Success (2002).

93 Launched in a series of speeches whilst still in opposition, see Blair, New Britain: My Vision of a Young Country (1996) Part III.

94 See Hall, 'The Meaning of New Times' in Hall and Jacques op. cit., n.90, p.116.

95 This has led to a break with many post-Marxists for whom the essence of democratic politics lies in 'agonistic pluralism': see C. Mouffe, The Democratic Paradox (2000) chap.5, and Hall, 'The Great Moving Nowhere Show' Marxism Today (1998) 9.

96 See M. Watson and C. Hay, 'The Discourse of Globalisation and the Logic of No Alternative: Rendering the Contingent Necessary in the Political Economy of New Labour' (2003) 31 Policy \& Politics 289. For Watson and Hay this was a political choice but others on the left see the processes of globalization as genuinely constraining e.g. D. Coates, 'Capitalist Models and Social Democracy: the Case of New Labour’ (2001) 3 Brit. J. of Pol. \& Int. Rel. 284. 
the two by opting for a model based on equality of opportunity, thereby consigning equality of outcome (with its dampening effect on enterprise and re-distributive focus) to history. This conception of social justice enables the state to portray much of its activity as a technocratic or managerialist response to structural changes affecting the whole of society, ${ }^{97}$ whilst simultaneously devolving much of the responsibility for outcomes to individuals through their actions in the marketplace.

On this basis it is unsurprising that communitarianism has thus proved to be much more palatable than stakeholding as an organizing principle, for it allows issues to be addressed to an inclusive non-sectional audience, and '... offers Labour modernizers a political vocabulary which eshews market individualism, but not capitalism, and which imbues collective action but not class or the state. ${ }^{98}$ As such, the aspects of stakeholding that are too reminiscent of Old Labour, especially the corporatist and Keynesian elements in Will Hutton's version, ${ }^{99}$ are neatly avoided. However, the stakeholder concept was formulated very much with the large company in mind as a means of generating active space for the exercise of voice and the demonstration of accountability over corporate decisions. ${ }^{100}$ Communitarianism by contrast, although also a broad concept which permits of many shades of meaning, has under New Labour tended to be of a conservative and prescriptive ilk. ${ }^{101}$ Further, whilst New Labour has been keen to stress the responsibilities of individuals (e.g. the principle of conditionality to welfare rights) within this framework, ${ }^{102}$ responsibilities in the corporate sector have been placed on a much more voluntarist footing within a context that has come to be dominated by the need for light regulation and low constraints on business actors. ${ }^{103}$ In sum, the organizational strand of the New Times analysis has led New Labour to a world view dominated by global capital and in which community is primarily a resource for individuals to face technological imperatives rather than a collective public realm to generate countervailing values to those of market individualism. ${ }^{104}$

\section{Giddens and Post-Traditional Society}

As the chief architect of the 'Third Way' there can be no doubt of Giddens' influence upon New Labour. ${ }^{105}$ That his politics spring from his

97 See Finlayson, op. cit., n.89, p.274.

98 Driver and Martell, 'New Labour: Culture and Economy' in L. Ray and A. Sayer eds., Culture and Economy after the Cultural Turn (1999) 255.

99 W. Hutton, The State We're In (1995); The State to Come (1997); and The Stakeholding Society (1999).

100 ibid. See also G. Kelly, D. Kelly and A. Gamble, eds., Stakeholder Capitalism (1997).

101 Driver and Martell, op. cit., n.98.

102 See N. Rose, 'Inventiveness in Politics' (1999) 28 Economy \& Society 467.

103 See Blair's speech to the IPPR (26 May 2005). For a discussion of how business interests led to preference accommodation (as opposed to preference shaping) by New Labour pursuant to the modified structural dependence thesis see Hay, The Political Economy of New Labour (1997) chap.5.

104 See further, Marquand, op. cit., n.80, chap.5.

105 There are, however, clear differences between Blair and Giddens as the former takes a rather neo-liberal view of both globalization and individualism: see 
understanding of radically new social facts, as Finlayson suggests, would seem equally incontestable:

"Revisionist social democracy starts from the reality of a structural transformation in the economy and society. It responds to intensifying global economic competition; the rise of a service and knowledge-based economy ... and to the rise of a pervasive cultural individualism, itself linked to a decline in deference ..."106

However, neither stakeholding nor community figure significantly in Giddens' account, which is determined principally by his investigation into the nature of the individual in high modernity. ${ }^{107}$ The three key elements of his analysis are globalization, the emergence of a post-traditional order and the expansion of social reflexivity. The processes of globalization are important, not primarily in an economic sense, but due to the compression of time and space that they allow. Globalization thus entails continual disembedding, by which interaction is lifted out from the particularities of locales. Individuals are thus required to subject both their understanding and experience of a disembedded interaction to critical interrogation so as to reassemble them reflexively, and thereby gain meaningful purchase on the social world. However, this very process also re-constitutes the interaction itself, and for Giddens post-traditional societies are thus irredeemably reflexive. Equally, such societies also operate at the edge of Enlightenment rationalism, as the far-reaching interventions so enabled (particularly in the scientific field) have generated manufactured risk, which, in turn, creates uncertainties not amenable to expert resolution. ${ }^{108}$

The effect on the human self is quite profound. In traditional societies an individual's space for action and ontological security was largely determined by received tradition and mediated authority (to a significant extent replaced by collective modes of assurance based upon Enlightenment rationality (e.g. bureaucracies) in early modernity). However, disembedding is hostile to received tradition, and thus in a post-traditional society it is in Giddens' view necessary for each individual reflexively to create their own biography. ${ }^{109}$ It is primarily in this frame that Giddens rejects both Keynesian economic management ${ }^{110}$ and neo-conservative communitarian attempts to ground the self. ${ }^{111}$ Instead, the individual in high modernity needs to develop an autotelic self, which term:

“. . . refers to a person able to translate potential threats into rewarding challenges, someone who is able to turn entropy

further, Driver and Martell, 'Left, Right and the Third Way' in Giddens ed., (2001), op. cit., n.2, pp.43-5.

106 Giddens and Diamond eds., op. cit., n.2, p.1. This position has been consistent from the outset: see Giddens (1998), op. cit., n.2, p.26.

107 The following account draws upon Giddens, Modernity and Self-Identity (1991) and Beyond Left and Right (1994) (hereafter 'Left and Right').

108 Giddens (1991), ibid., p.31.

109 Class is thus no longer experienced simply as 'collective fate': Left and Right, pp.143-4.

110 It is hard to direct individuals in a reflexive world: ibid., p.42.

111 Such communities oppress individual autonomy: ibid., pp.124-6. 
into a consistent flow of experience ... [and who] does not seek to neutralize risk ... [which] is confronted as the active challenge which generates self-actualization." 112

Through the combination of this view of the self and the enabling role that is the primary avenue of action left to the state under a regime of reflexive modernity, Giddens also regards the broad field of politics as being radically changed. In early modernity the characteristic political mode was to be found in emancipatory politics, which sought to free individuals from tradition and mobilized collective power in order to achieve equal access to civil, political and social rights. By contrast, the focus in a period of reflexive modernity is perforce upon life politics, which is both generative and dialogical, and centres on questions of identity construction and lifestyle choice. ${ }^{113}$ Politics has, in this sense, thus moved beyond the conflictual collective left/right dichotomy and the structure of power in society has been accordingly re-configured. ${ }^{114}$ In essence, Giddens' social democracy seeks to enable all members of society to participate in life politics, and this aim is reflected in a movement away from issues of substantive equality, ${ }^{115}$ to a concern with avoiding social exclusion, especially from the employment market. ${ }^{116}$

It is easy to see how a self conceived on such a basis potentially maps onto the market individualist required by neo-liberal enterprise culture. However, Giddens is clearly opposed to the reductive atomistic version of individualism propounded by neo-liberals, which he characterises as solely concerned with '. . . the self-seeking, profit-maximising behaviour of the marketplace.' ${ }^{117}$ Instead, for Giddens the core of individualism lies in embedded autonomy:

"[i]n a world of high reflexivity, an individual must achieve a certain degree of autonomy of action as a condition of being able to survive and forge a life; but autonomy is not the same as egotism and moreover implies reciprocity and interdependence. The issue of reconstructing social solidarities should not therefore be seen as one of protecting social

112 ibid., p.192. This notion of the self as both resolutely rational and infinitely plastic has been subject to critique: for a brief overview see A. Elliott, Concepts of the Self (2001) 36-45.

113 Giddens (1991), op. cit., n.107, chap.7.

114 See, e.g. Giddens and Diamond eds., op. cit., n.2, pp.106-8. It is precisely the fact that '[r]elations of power and their constitutive role in society are obliterated' in Giddens' thought, that in many critics eyes prevents Giddens from confronting the '.. systemic problems of inequality and instability generated by capitalism': see Mouffe, op. cit., n.95, pp.110-12; and generally A. Callincos, Against the Third Way (2001).

115 See Giddens (2000), op. cit., n.2, chap.4. For an argument that the rationale of life politics is too sharply distinguished from emancipatory issues and is liable to subversion by economic/market logic, see N. Mouzelis, 'Reflexive Modernization and the Third Way: the Impasses of Giddens' Social-Democratic Politics' (2001) The Sociological Review 436.

116 Full employment is central to social justice: Giddens and Diamond eds., op. cit., n.2, p. 108 .

117 Left and Right, p.13. 


\section{Northern Ireland Legal Quarterly [Vol. 56, No. 4]}

cohesion around the edges of an egoistic marketplace. It should be understood as one of reconciling autonomy and interdependence in the various spheres of social life, including the economic domain." 118

However, there would seem to be a fault line through Giddens' thinking which rests on his ambivalent view of markets. For although markets bring freedom, dynamism, and innovation, the problems arising for social cohesion and solidarities are also clear. ${ }^{119}$ Ultimately, however, Giddens' position is determined by the fact that there is no practical alternative. ${ }^{120}$ It is thus made patent that the new egalitarianism proposed in his latest work pragmatically falls short of redistributive social justice, due to the need to accommodate economic imperatives. ${ }^{121}$ But such economic imperialism presents serious difficulties for the autotelic self and for a politics based upon values, for as Lawrence Mitchell has put it:

"The critical problem in the age of markets is that we have yet to develop appropriate norms, rules, and social structures to accompany it, social structures that are necessary to bring some stability and order . . . to the volatile and chaotic market environment in which we now live ... The result is anxiety, resentment, fear, self-interest, and competition without regard to others. The result is the ethic of fear. And the ethic of fear threatens cooperation, compassion and fairness within our society." 122

Mitchell concludes, rather ominously, that '[i]n the absence of consciously created social norms and social institutions to counter the destabilizing effects of the market, society itself is at risk of becoming nothing other than an economic arena.' 123

Such a danger is enhanced by the presence of the company as a dominant institution in society, with the sole raison d'être of being an efficient market actor. Indeed, Giddens' early analysis of the new socio-political realities led him to muse that, 'the globalizing of capitalist economic relations would seem on the face of things to leave large corporations in a dominant position within the economies of states and in the world economy as a whole'124 However, having identified the potential of corporate collective power, Giddens concludes that this prima facie situation would in reality only present difficulties if the company obtained a monopoly. Whilst this conclusion has an unfortunate resonance with that of Friedman examined earlier, it is ventured that Giddens' reasoning is more likely to be based upon

8 ibid.

119 ibid., pp.10-11.

120 In this respect, at least, Giddens frequently commends the truth of Francis Fukuyama's, End of History and the Last Man (1992): see e.g. Hutton and Giddens eds., op. cit., n.2, p.11.

121 Giddens and Diamond, op. cit., n.2, pp.108-9.

122 Mitchell, 'The Age of Aquarius or, How (I almost) Learned to Stop Worrying and Love Free Markets' (2004) 88 Minn. L. Rev. 921, 949.

123 ibid., p.953. The problem is one that the Victorians also struggled with: see G. R. Searle, Morality and the Market in Victorian Britain (1998).

124 Left and Right, p.89. 
his general diffuse view of power and upon his specific understanding of the development of the flattened hierarchies characteristic of post-Fordist companies as a response to the need for greater reflexivity. ${ }^{125}$

However, as his thinking has evolved, Giddens has become considerably less sanguine about the realities of corporate power. He has acknowledged that early progressive theory had been too accepting of business and that 'as a result of two decades of neoliberal dominance, the business world is threatening to erode its own mandate to operate.' 126 By way of a solution Giddens has started to explore the need for a civil economy and for the development of corporate citizenship and social responsibility. ${ }^{127}$

\section{Corporate Personality and Corporate Law Reform}

It maybe objected that much ink has already been spilt on the thorny topic of identifying the precise jurisprudential basis of corporate identity without generating any single agreed substantive model, and that any form of essentialist argument seeking to ground the nature of corporate personality is accordingly inappropriate and thus doomed to failure. Such was indeed the import of John Dewey's classic article in 1923, which amounted to a summation of the intellectual debate on the corporate form that had raged across the Atlantic at the beginning of the twentieth century, and in which Dewey's clear conclusion was that, 'for the purposes of law the conception of "person" is a legal conception; put roughly, "person" signifies what law makes it signify'. ${ }^{28}$ However, Dewey's central argument is not fatal to the nature of the investigation envisaged here, which, instead, builds upon his wider observation that any theory of corporate personality is infused with materials 'logically extraneous' to the exercise of legal definition. Accordingly, being impressed with conflicts of both a political and an economic nature, corporate theory is inevitably plural. ${ }^{129}$

For current purposes only a brief overview of this rich tapestry is possible, and it is proposed to concentrate upon three key domains: the nexus of contracts model; the doctrinal position; and stakeholder models. The nexus of contracts model of the company forms a significant element of the law and

125 'A post-bureaucratic organization can both harness social reflexivity and respond to situations of manufactured uncertainty much more effectively than a command system': ibid., p.122.

126 Giddens ed., (2003), op. cit., n.2, p.11. On New Labour's need to address its 'overly cosy relationship with business' see P. Mandelson, The Blair Revolution Revisited (2002) p. xlvi.

127 See Giddens and Diamond op. cit., n.2, pp.112-3; Giddens ed., (2003), op. cit., n.2, pp.6-12; and Giddens (2000) op. cit., n.2, pp.142-153. An important contribution has also been made in developing the concept of an embedded market whereby the social values of communities are the principal regulators of economic life: see further, J. Kay, 'The Embedded Market' in Giddens ed., (2003), ibid., pp.35-53; and The Truth about Markets (2003).

128 J. Dewey, 'The Historic Background of Corporate Legal Personality' (1926) 35 Yale L. J. 655. See also H.L.A. Hart, Essays in Jurisprudence and Philosophy (1983) 21-48.

129 See e.g. D. Millon, 'Theories of the Corporation' (1990) Duke LJ 201; and M. Hagar, "Bodies Politic: the Progressive History of Organizational "Real Entity" Theory’ (1989) 50 Univ. Pitt. L. R. 575. 
economics scholarship that is currently the dominant mode of analysis in Anglo-American thinking on the subject ${ }^{130}$ and has clearly been influential in the recent corporate law reform process. ${ }^{131}$ In essence, the company is conceived in contractual terms as a network of explicit and implicit bargains made between the participants in the enterprise. The analytical emphasis thereafter is placed upon dealing with the problems of the agency costs arising. In the model's purest form, the distinctive notion of the company as a separate legal person is thus rendered theoretically superfluous to the principal investigation. ${ }^{132}$ For present purposes the point of interest lies in this radical 'deconstruction' of the corporate entity, which arguably symbolically seeks to remove corporate collective power from the wider public political agenda, either as part of an explicit anti-regulatory neoliberal approach, or more usually, so as to deal with the complex agency problems at the level of detailed microeconomics. ${ }^{133}$

The extent to which the judiciary has been influenced by the nexus of contracts theory is not easy to ascertain. The lack of explicit reference to it within judgments is to be expected, as its abstract modelling is not easy to integrate with the traditional mode of reasoning employed in the common law. If the most that might therefore be found is an echo, then it is arguable that such a resonance may be detected in the leading modern case on corporate personality, Meridian Global Funds Management Asia Ltd. v Securities Commission. ${ }^{134}$ The details of the case are not important, save that it concerned the need to attribute knowledge to a company. In his opinion on behalf of the Privy Council, Lord Hoffmann sought to move away from organic metaphors of the company ${ }^{135}$ and move towards a set of primary and general rules of attribution drawn from the company's constitution and the general law respectively. In so doing Lord Hoffmann expressed the following view of corporate personality:

130 See e.g. F. Easterbrook and D. Fischel, The Economic Structure of Corporate Law (1991); and B.R. Cheffins, Company Law: Theory, Structure and Operation (1997). For critiques see e.g. Ireland, 'Property and Contract in Contemporary Corporate Theory' (2003) 23 L.S. 453; and W.W. Bratton, 'The Economic Structure of the Post-Contractual Corporation' (1992) 87 Northwestern U. L. R. 180.

131 See especially, Company Directors: Regulating Conflicts of Interests and Formulating a Statement of Duties (1999: Law. Com. No. 261; Scot. Law. Com. No. 173) Part II.

132 See the points noted in Cheffins, op. cit., n.130, p.32.

133 For recent valuable contributions to this analysis see: ibid., and R. Kraakman et al., The Anatomy of Corporate Law (2004). It is notable that in order to contextualize their agency analysis Hansmann and Kraakman have to explain corporate legal personality and limited liability by way of a property-based argument (by what they term affirmative and defensive asset partitioning respectively) and, as Ireland notes, that this move breaks open any model based on the essential 'private, contractual nature of corporations' to allow a more radical governance regime based on their social power: see Ireland, op. cit., n.130, p.509.

134 [1995] 2 A.C. 500 (P.C.)

135 See e.g. the judgment of Denning LJ in H.L. Bolton Engineering Ltd $\mathrm{v}$ T.J. Graham \& Sons Ltd [1957] 1 Q.B. 159, 172 (C.A.). 
“. . . reference to a company 'as such' might suggest that there is something out there called the company of which one can meaningfully say that it can or cannot do something. There is in fact no such thing as the company as such . . . only the applicable rules [of attribution]." 136

On the particular facts of the case the relevant knowledge was attributed to the company by way of a special rule of attribution determined by a purposive construction of the relevant legislation. There are two paradoxes here: first, the notion of attribution requires an attributee; and secondly, in denying the existence of the company 'as such' Lord Hoffmann was actually extending the scope of corporate liability. ${ }^{137}$

By way of contrast, stakeholding models of the company are generally premised upon a strong notion of the corporation as the seat of significant power over the various constituencies with an interest in its operations. ${ }^{138}$ The theoretical focus is thus to ensure that the corporate form is analysed within the full social, economic and political context in which it functions, so as to ensure that appropriate governance mechanisms are in place. The primary responses to this enquiry have been to seek to place directors under a fiduciary duty to each stakeholder, to encourage formal employee participation in corporate decision-making, and to foster corporate social responsibility. ${ }^{139}$ Stakeholding thus has distinctly corporatist overtones and, as such, has proved politically unattractive to New Labour. ${ }^{140}$ In addition, these overtones are amplified by the ongoing debate between the individualist and corporatist modes of capitalism ${ }^{141}$ within the European Union, ${ }^{142}$ and the more general contemporary focus on corporate governance regimes as a site of national comparative economic advantage. ${ }^{143}$ As might

136 [1995] 2 A.C. 506H-507A.

137 For commentaries on the decision see: N. Lacey, 'Philosophical Foundations of the Common Law: Social not Metaphysical' in J. Horder ed., Oxford Essays in Jurisprudence (2000) 17; and G. R. Sullivan, 'The Attribution of Culpability to Limited Companies' [1996] C.L.J. 515.

138 See e.g. Parkinson, op. cit., n.31; and Mitchell ed., Progressive Corporate Law (1995). For a critique, from a person sympathetic to both Third Way politics and a thoroughly contextualized view of the corporation as a social actor, see S. Wheeler, Corporations and the Third Way (2002) 29-33.

139 See the influential pieces by M. Stokes, 'Company Law and Legal Theory' in W. Twinning ed., Legal Theory and Common Law (1986) 155; and Lord Wedderburn, 'The Social Responsibility of Companies' (1985) 15 Melbourne U. L. R. 4.

140 Despite early dalliances as noted above in the main text: see also J. Plender, $A$ Stake in the Future (1997); and Driver and Martell (1998), op. cit., n.85, pp.5160.

141 For an early account see M. Albert, Capitalism Against Capitalism (1993).

142 It is a clear undercurrent in the rejuvenated Lisbon Agenda, where the social model seems to become less prominent in each of the following documents: Facing the Challenge: The Lisbon Strategy for Growth and Employment Report from the High Level Group chaired by Wim Kok (November 2004); Communication of the Commission to the European Council COM(2005) 24 (2 February 2005); and Brussels European Council Presidency Conclusions 7619/05 (23 March 2005).

143 For a comprehensive overview of the debate see: K. J. Hopt et al., eds., Comparative Corporate Governance (1998); J. A. McCahery et al., eds., 
be imagined from the previous discussion the individualist model is favoured by the United Kingdom, as it is seen as more flexible and dynamic in a world of change. ${ }^{144}$ The European social model, by contrast, although encouraging long-term investments, is perceived as too cumbersome, and as overly insulating various interlocking elites from wider accountability and market pressures. ${ }^{145}$

All things considered it is thus hardly surprising that the government has not proceeded with stakeholder models in its proposals for company law reform. In fairness, the government is largely following the recommendations of the Independent Company Law Review that it instigated in 1998 with the object of ensuring that the United Kingdom had an appropriate regulatory framework to maintain a competitive corporate regime in the globalized economy of the new millennium. ${ }^{146}$ The Review did in fact consider the basis of company law by reviewing the content of the company directors' duties; and generated two models: the enlightened shareholder model (which was generally agreed to represent the existing law that companies should be run with a priority to shareholders interests) and the pluralist model. ${ }^{147}$ The latter was in effect stakeholding under a different guise and was based not only on the benefits of fostering co-operative long-term relationships but also on economic analysis. The underlying economic reasoning was that shareholders were not the only residual risk bearers in the company as other stakeholders also made firm specific investments and were unable to protect themselves by writing complete contracts. In order to maximise the company's overall wealth creation it was thus necessary to optimise each stakeholders' firm specific investment by allocating governance rights beyond simply the shareholders. ${ }^{148}$

Whilst the pluralist model was rejected (principally due to the accountability and enforcement problems arising from a multi-fiduciary duty) its proponents could claim that it left its imprint upon the inclusive shareholder

Corporate Governance Regimes (2002); and J. N. Gordon and M. J. Roe eds., Convergence and Persistence in Corporate Governance (2004).

144 Blair's speech to the European Parliament (23 June 2005) on the revitalized Lisbon Agenda attempts to mitigate the individualism but is clear that the social model requires modernization.

145 See Giddens (2000), op. cit., n.2, pp.151-3. Giddens' disagreement with Hutton on these issues is best brought out in their conversation reported in Hutton and Giddens eds., op. cit., n.2, pp.1-51. Whilst some political scientists believe that the social model continues to offer comparative institutional advantage others are more sceptical about its continuing ability to generate outcomes for labour that are superior to individualist models, see respectively: P.A. Hall and D. Soskice eds., Varieties of Capitalism (2001) 1-68; and Coates, Models of Capitalism (2000) 259-60.

146 The White Papers are set out in n.1. For a detailed commentary on the review process by its director, see J. Rickford, 'A History of the Company Law Review' in J. de Lacy ed., The Reform of United Kingdom Company Law (2002) 3.

147 For details see ibid., and G. Wilson, 'Business, State, and Community: 'Responsible Risk Takers', New Labour and the Governance of Corporate Business' (2000) 27 J. of Law \& Soc 151.

148 See G. Kelly and J. Parkinson 'The Conceptual Foundations of the Company: a Pluralist Approach' in Parkinson et al., eds., The Political Economy of the Company (2000) 113. 
duty that was the outcome of the Review, and that has been adopted, in slightly modified form, by the government. ${ }^{149}$ Pursuant to the proposed new statutory duty company directors must act in the manner they 'consider, in good faith, would be most likely to promote the success of the company for the benefit of its members as a whole'. ${ }^{150}$ In determining this they must, so far as reasonably practicable, take account of likely short and long term effects of the decision on the community and environment together with the interests of employees, customers, suppliers and the company's own need to maintain a reputation for high standards of business conduct. As the primary duty is to enhance shareholder benefit and remains owed to the company, this is clearly not a stakeholder approach. However, although there may be some devil in the detail, it does, symbolically at least, open the company up to the outside environment and thus clearly renders it a visible legal actor (both to external and internal participants) therein. When combined with the regular disclosure of information by quoted companies under the new Operating and Financial Review, there is thus some cause for hope that corporate power will be exercised in a context more open to wider cultural values, and that reputational concerns in the market might be harnessed to ratchet-up corporate behaviour. ${ }^{151}$

However, for Sally Wheeler, the fact that the Review frames corporate relations 'in a context of increasing competitiveness displays a worrying emphasis on the importance of the market as an institution divorced from wider concerns such as inclusion and shared advancement.' ${ }^{152}$ An ethical framework that fosters the latter values is vital if the company is to relegitimate itself within society; and is central to Third Way philosophy, which seeks to re-unite the individual and the collective by way of voluntary action. ${ }^{153}$ Wheeler, therefore, advocates that corporations should be treated seriously as individual actors and encouraged to participate in the polis, so as to realise themselves as virtuous citizens. Such corporate intervention (running in tandem with profit-making activities) would be actioned via partnership with Regional Development Agencies, assessed by way of need audits, and implemented through care plans. ${ }^{154}$ The consequence would be

149 Space does not permit a detailed examination of the primary sources, see further: Rickford, op. cit., n.146, pp.15, 22 and 36-7; and Parkinson, 'The Inclusive Company' in de Lacy ed., op. cit., n.146, p.43, especially pp.44-52. The proposed statement of directors' duties is set out in the Corporate Law Reform Bill, clauses B1-8 (note that the detailed wording is significantly different to the previous draft Companies Bill in Modernising Company Law (July 2002; Cm 5553-II)).

150 Corporate Law Reform Bill, clause B 3(1).

151 See the excellent discussion in Parkinson, 'Disclosure and Corporate Social and Environmental Performance: Competitiveness and Enterprise in a Broader Social Frame' (2003) 3 J. Corp. Law Studies 3.

152 Wheeler, op. cit., n.138, p.51.

153 Wheeler founds corporate ethical behaviour in Aristotelian virtue ethics and utilizes the work of Alasdair MacIntyre to generate a liberal localized conception of community.

154 It is interesting to speculate whether situating the corporate form in this conceptual framework would ameliorate the massive disparity in general health that has been shown to beset societies in which there are large inequalities: see R. Wilkinson, 'Social Corrosion, Inequity and Health' in Giddens and Diamond eds., op. cit. n. 2, 183, and The Impact of Inequality: How to Make Sick Societies 
that corporations would both practically apply the kind of values that New Labour seeks to espouse as a basis for progressive politics and see 'themselves as contributing to the accumulated good of all other individuals and not as in some way hosted by a wider society and yet separate from it.' ${ }^{155}$

\section{Conclusion}

It has been noted both, that the Labour Party has demonstrated surprisingly little interest in the underlying principles of company law during its history, ${ }^{156}$ and that '[c] ompany law has been seen as an apolitical, technical subject concerned solely with the rules of private law' ${ }^{157}$ However, for a progressive social democratic politics to prevail, and for the values and rationality of the market individualist not to successfully colonise other spheres of society, it is vital to recognise the power of corporate agency and for the company to be brought within dialogical engagement with other societal groups. ${ }^{158}$ To this end the proposed company law reforms offer a chink of light in that company directors will be under a duty to at least identify the factors relevant to a corporate decision and the increased disclosure provisions will enhance the visibility of corporate activity. Nevertheless, whilst of some symbolic value, a significant limitation of the reforms may be said to lie in the fact that the enforcement of duties remains principally with the company itself. Taken as a whole the effect the reform package is thus that the corporation remains subject to discipline contoured principally by market rationalities. ${ }^{159}$ Given New Labour's tendency to adopt market solutions this outcome is doubtless not too surprising, but it is unfortunate that Giddens has not developed his notion of a civil economy with more urgency in the light of his increasing disquiet with aspects of corporate capitalism. It may be that Wheeler's radical vision of the corporate entity provides the type of utopian thinking required, for otherwise the combination of largely unacknowledged corporate collective power and market individualism might yet result in a society such as that depicted by Kurkov's novels on the anarchic capitalism of post-Soviet Ukraine: 'It was all money, money, money today. Ideology was out.' ${ }^{\prime 60}$

Healthier (2005). For a telling analysis of the inequalities arising from the shareholder-orientated model of the corporation, see Ireland, 'Shareholder Primacy and the Distribution of Wealth' (2005) 68 M.L.R. 49.

155 Wheeler, op. cit., n.138, p.80.

156 See B. Clift, A. Gamble and M. Harris, 'The Labour Party and the Company' in Parkinson et al., eds., op. cit., n.148, p.51.

157 C. Graham, 'Regulating the Company' in Hancher \& Moran eds., op. cit., n.51, p.199.

158 Such dialogue has a double-edged quality, as it may also extend corporate influence: see Parkinson, 'Participation and Corporate Governance' in Campbell and Lewis eds., op. cit., n.76, p.319, especially pp.344-7.

159 The inadequacy of which is well demonstrated by Ireland, 'Recontractualising the Corporation: Implicit Contract as Ideology' in D. Campbell et al., eds., Implicit Dimensions of Contract (2003) 255, especially 287-8. See also the recent polemical dissection of corporate power in the United States by Galbraith in The Economics of Innocent Fraud (2004).

160 Kurkov, The Case of the General's Thumb (2004) 137, translated by G. Bird. A view that Mitchell seems close to sharing about the present state of corporate America: see Mitchell, Corporate Irresponsibility (2001) 93-4, 258-9. 